\title{
Research on Educational Innovation in Specific Educational Work of Colleges and Universities
}

\author{
Tao Yan \\ Xi'an Fanyi University, 710105 Xi'an China
}

Keywords: Educational innovation, Management model, Strategy, Research, Analysis

\begin{abstract}
Improvement of teaching quality and change of teaching management model are key points of educational innovation in colleges and universities at the present stage, and are constant subjects in the educational field as well. The primary premise for guaranteeing education quality is controlling and managing teaching quality. At present, due to continuous extension of scale of colleges and universities and necessities in development of modern society in our country, educational innovation in colleges and universities will face new challenges. This article mainly analyses specific issues existing in the specific work of educational innovation in colleges and universities in China and conclude corresponding solutions, thus providing references for building new educational innovation model of colleges and universities and enhancing teaching quality of colleges and universities.
\end{abstract}

\section{Introduction}

Along with change of times and development of society, traditional teaching model of curriculum of many majors in colleges and universities in our country needs to be changed to adapt trend of development of the times. A lot of problems still exist in the teaching process and solutions shall be found in time. Rapid development of contemporary society puts forward new standards for quality of talents, which makes traditional teaching management model in colleges and universities no longer fully adapting to development of modern society, so that new teaching model in colleges and universities is needed. Educational innovation in specific teaching work shall be carried out to try new teaching idea and explore teaching models more adaptable to the trends. Except for focusing on training specialized skills, education of modern colleges and universities shall conform to situation of humanistic quality and economic development as well, so as to ensure students in colleges and universities better meet requirements of social development in the future life.

\section{Purpose and Importance of Building New Teaching Quality Management Model in Colleges and Universities to Carry out Educational Innovation}

Management is the soul of development, so that quality of managers shall be emphasized in the management model of teaching quality in colleges and universities in order to guarantee highquality education in colleges and universities. Only by focusing on building a people-oriented management system, promoting school-running standards of colleges and universities with scientific and democratic management model and motivating working enthusiasm of teachers in colleges and universities, can the teaching and management quality be improved. Improvement of teaching quality and reform of management model are keys for healthy, stable and sustainable development of educational innovation in colleges and universities.

\section{Key Issues in Educational Innovation of Educational Work in Colleges and Universities}

First of all, standardization and targeting of management model shall be paid attention to. Target is the heart for realizing effective management of teams and development of colleges and universities is achieved through standardized management model. Only by building a time-based management system to ensure clear responsibility, whole progressing and innovation and pragmatism, can colleges and universities grow healthily. Secondly, management system of competition and 
motivation shall be attached importance to. Motivation is an important way to enhance cohesion of teaching faculty in colleges and universities, so incentive mechanism can surpass all management systems in colleges and universities if it is applied appropriately. Emotions of teachers at work are fully mobilized by the incentive mechanism, but appropriate competitive mechanism is needed as well. Progresses are made along with competitions, so traditional management system shall be reformed and high-class system of rewards and penalties shall be set. Thirdly, operability of management system shall be taken into account. Practical management system is the management mechanism to promote development of colleges and universities, guarantee high-quality and highefficient teaching achievements and enhance cohesion of staffs. Development goal and management system conforming to current status of each post shall be set, and accurate assessment to work of teachers in the means of performance evaluation shall be implemented, so as to improve responsibility consciousness of teachers and promote healthy and orderly development of management system. Fourthly, specific model of incentive mechanism shall be emphasized. Taking salary as an effective model to motivate development of teachers in colleges and universities can let teachers have a true feeling that salary is appreciation and acceptance to their work. Performance appraisal and flexible salary can stimulate teachers to work harder.

\section{Specific Issues Existing in Educational Innovation of Educational Work in Colleges and Universities at Present Stage}

Cultural Accumulation of Students is Neglected in Educational Management Model of Colleges and Universities. Requirements on assessment of cultural courses and humanistic quality of students at the entrance examination are relatively strict though, such requirements in colleges and universities at present stage are not strict. Students in colleges and universities pay less attention to cultural accumulation, which leads to a result that students in colleges and universities fall behind rather than making progresses. If lack of attention to humanistic quality and personal cultivation by colleges and universities and students is allowed to continue like this, cultural accumulation of students in colleges and universities may suffer and it may inevitably generate unfavorable influences to the future development of students in colleges and universities.

Old-Fashioned Teaching Methods and Teaching Contents in Teaching Management Model of Colleges and Universities. At present stage, many courses in colleges and universities are still in the rigid pattern of students learning from what teachers teaching, and communication and interaction between teachers and students are ignored. This rigid pattern is no good for motivating students in class, and if students are interested in classroom teaching, their progresses in academic records are affected. Teaching contents are conventional and empty. During teaching of major courses, teachers in colleges and universities lay too much emphasis on knowledge of specific major and ignore education and training of comprehensive quality of students.

Shaping of Outlook of Life and Value of Students Is Neglected in Educational Management Model of Colleges and Universities. Influenced by atmosphere of the outside world, many teachers in colleges and universities cannot put their hearts into researches and teaching, instead they overly concern about their own reputations, interests, development and status. Because students are in a unstable formation period of ideology and value, such atmosphere of teachers will unconsciously influence students and will bring negative influences on healthy formation of outlook on life and value of students.

Lack of Trainings on Innovation Ability of Students in Educational Management Model of Colleges and Universities. If teachers in colleges and universities use traditional and single teaching model in the class, thoughts of students will be fixed in a uniform model, which will block trainings on innovation ability of students and constrain active and exploration thoughts of students. As a result, atmosphere in the classroom is poor and communications and interactions between teachers and students are lacked, which are bad for training innovation ability of students. 


\section{Analysis on Solutions to Problems Existing In Educational Innovation in Colleges and Universities}

Advocating General Management and Paying Attention to Cultivation of Comprehensive Quality of Students. It is important to take future career development and ability development of students in colleges and universities into consideration based on emphasizing comprehensive abilities. It is not enough for students to possess excellent specialized knowledge and skills. Only by improving comprehensive abilities, can students achieve sound progress in the future career and be recognized by other people. In traditional teaching system, trainings on comprehensive abilities and quality of students are lacked. Students are restricted that future development of students is seriously blocked as a result. Therefore, it is important for colleges and universities, during teaching management process, to observe and enhance rights of creative students and pay attention to cultural knowledge of students so as to let students develop in an -all-round way. Only by enhancing comprehensive quality of students, can they achieve better development in overall quality of the future study and living. Therefore, except for specialized courses of related professional skills, cultural courses for improving quality of students shall be established as well, thus improving social adaptability of students. Besides, overall teaching quality can be improved, and the students can have a smoother and steadier future social life.

Abandoning Old-Fashioned Thoughts in the Teaching Management Model. He traditional teaching management in colleges and universities applies a rigid and fixed model which only focuses on specialized knowledge of students rather than paying attention to abilities of students or taking cultivating abilities of students as basic target. The traditional model creates students with high scores and low abilities. In order to change this situation, we need to adapt to the current new model of teaching management and social development and regard improving abilities of students as the fundamental purpose. We need to establish a student-centered teaching philosophy that focuses on creativity and innovation of students so as to let all students participate in classroom teaching, thus improving classroom teaching atmosphere, motivating students and training thoughts and practical ability of students.

Paying Attention to Management on Outlook of Life and Value of Students. In colleges and universities, it is important to impart specialized skills to students, but for a complete teaching management, students shall also possess proficient abilities to adapt to practical work. So during the process of imparting specialized knowledge and student management, life and cultural values shall be included as well. Careers students love by instincts can motivate learning initiative and ability to resist infection of students, thus purifying spirits of students and letting them regard their specialized knowledge as a life-long love. Only in this way can students overcome all difficulties occurring in the future learning and work, and only such students can express what they have learned comprehensively and perfectly. Thus it can be seen that outlook of life and value of students are extremely important.

Laying Emphasis on Guidance of Creative Spirit in New Teaching Quality Management Model. In teaching quality management model, a type of student-oriented model with inspiration, exploration and discussion is lacked, and questions of students can bring thinking activities. Traditional and single teaching model suppresses students to uniform thoughts. It is necessary to change this teaching management model in colleges and universities. If colleges and universities want to cultivate high-quality specialized talents with creative thoughts, that must tap creative potentials of students. There will not be development without innovation. In order to improve innovative ability of students, selection of teaching environment shall make fascinating plots to extend feelings of students and motivate resonance of students so as to let students have specific feelings and correct understandings on the teaching contents. And then thinking ability and exploring ability of students is motivated and rigid and dated teaching quality management model in colleges and universities are improved. If the classroom atmosphere is harmonious, teaching model in classroom is reformed and thoughts of student's divergent, then innovative ability will automatically be improved correspondingly. 


\section{Suggestions on New Teaching Quality Management Model in Educational Innovation in Colleges and Universities}

First of all, in the new teaching quality management model, students shall form correct outlook of life and value under guidance. Higher educational objective shall be put forward so as to grant students lifelong survival tools. Self-learning ability shall be paid attention to so that students can make progress through self-learning at any time in the future, thus realizing the objective of life-long education.

Secondly, a new textbook model of colleges and universities shall be set up in accordance with new scientific teaching law. Excellent elements of the traditional teaching model shall be absorbed, plus with the new modern teaching philosophy. Advanced teaching contents of foreign countries shall be used for references to promote teaching and educational reform in our country. Actual results of teaching system in local colleges and universities shall be regarded, researches and investigations shall be carried out actively, and brief summaries of feedback contents shall be made to promote rapid development of course reform and conclude a set of new situations suitable for domestic teaching management model within the shortest time.

Thirdly, teaching contents in colleges and universities shall put practical teaching in the first place. Practice embodies the prominent new functions of modern teaching, and only by attaching to this essence, teaching results of college courses can be reflected to the greatest extend. If students are interested in the practical contents, they will participate actively and then the classroom will become easier and simpler. Except for focusing on practicability, scientific teaching shall be improved as well. Only after the teaching contents become more scientific, can reform of teaching achieve final success. Teaching materials shall satisfy different basis and different level of students so that reform of teaching contents can be smoother.

Fourthly, in the new teaching quality management model, dominant role of students shall be laid emphasis on, and self-management ability and consciousness of students shall be improved. Management model reform of colleges and universities shall on basis of the basic target of personality development of students rather than relying on the old management model with severe problems; otherwise it will block development of creativity of students and lead to losing interests in innovation of students. As for curriculum setting, teachers shall give play to subjective initiative of students and offer opportunities to students to dominate the classroom. Cooperation and interaction between teachers and students shall be added in the curriculum so that students can express their thoughts and feelings thoroughly. Allowing students to reserve their opinions can not only improve teaching effectiveness but also improve innovation of students. Modern education must pay attention to the people-oriented educational concept, so as to mobilize initiative and enthusiasm of students, enhance guiding function of teachers, and encourage students to image, create, query and participate.

\section{Conclusion}

In conclusion, in modern society, in order to realize sustainable development, colleges and universities shall carry out education innovation, lay emphasis on reform and innovation in teaching quality management model, and take effective measures to promote overall management level of colleges and universities. Only with sound management system and complete management strategy, can colleges and universities develop smoothly and steadily. Therefore, building a new teaching quality management model of colleges and universities shall be emphasized to promote sustainable development of colleges and universities.

\section{References}

[1] Study on Teaching Management During Process of Popularization of Higher Education, Ge Youbing, Science \& Technology Information, 2012.

[2] Discussion on Requirements of Popularization of Higher Education on Management System Reform in Local Colleges and Universities, Li Shujuan, Learning Weekly, 2015. 
[3] Study on Innovation of Teaching Management Model of Secondary Schools of Local Colleges and Universities, Cui Fengzhen, Cui Haibo, Su Cuihong, College and University Education, 2014.

[4] Research on Student Management Mechanism Innovation of Universities under Background of Popularization of Higher Education, Wang Bin, Inner Mongolia Normal University, 2013.

[5] Brief Analysis on Innovation of Teaching Management System of Local Colleges and Universities, Zheng Yong, Zhang Yang, Education and Teaching Forum, 2013.

[6] Exploration and Practice of "Student-Oriented" Credit System Teaching Management Model of Local Engineering Colleges, Bao Gaobo, Zhang Jing and Gou Jianxin, etc. Journal of Hubei University of Automotive Technology, 2013.

[7] Promotion of Core Competitiveness of Local Colleges and Universities- Improving Teaching and Educational Quality Is Key, Shi Lusha, Educational Theory and Practice, 2012.

[8] Research on Development of Innovative Local Colleges and Universities, Zhou Qingming, Research on Development of Innovative Local Colleges and Universities, 2013. 